\title{
The Effect of Financial Literacy and Financial Technology on Student Financial Inclusion of Institute of Social Sciences and Management Stiami Jakarta Bekasi Campus
}

\author{
Ismi Amalia Romadhon ${ }^{\text {a, }, 1 * \text {, Heksawan Rahmadi }}{ }^{\text {b,2 }}$ \\ a,b Fakultas Ilmu Administrasi, Institut Stiami Jakarta \\ ${ }^{1}$ hexawanmaryoto@gmail.com * \\ * corresponding author
}

ARTICLE INFO

Article History

Received, 23-Okt-2020

Reviewed, 28-Okt-2020

Published, 31-Okt-2020

Keywords

FinancialLiteracy;

FinancialInclusion;

Fintech;

Financial Technology

\begin{abstract}
Financial inclusion is a situation where everyone has access to quality financial services at an affordable cost and a fun way. This research aims to find out the influence of literacy on financial inclusion, to know the influence of financial technolgy on financial inclusion on students of Institute of Social Sciences and Management STIAMI Jakarta Bekasi Campus. The population of this study was a student employee of STIAMI Institute of Social Sciences and Management Jakarta Bekasi Campus and was assigned a sample of 47 respondents, with the method of Simple Random Sampling. The study used questionnaire data collection techniques. Technical analysis of the data used is validity test, reliability, classic assumption, multiple linear, Correlation Coefficient, determination coefficient and hypothesis test. The results of the study based on the t test analysis showed that the financial literacy variable (XI) with a calculated $t$ value of $0.607>t$ table 2.01537 or signification $0.547>0.05$ and variable financial technology (X2) with a calculated value of $3.895>t$ table 2.01537 or signification of $0.000<0.05$, it is said that only financial technology variables (X2) have a significant effect on financial inclusion variables $(Y)$. While the $F$ test results show that independent variables (price and product quality) have a simultaneous influence on dependent variables (purchasing decisions) with a value of $F$ count $10,476>F$ table 3.20 or signification of 0.000 $<0.05$. so Ho was rejected and Ha accepted. Based on multiple linear regression analysis the model or equation is $Y=64,392+$ $0.095(X 1)+1,140(X 2)$.
\end{abstract}

\section{PENDAHULUAN}

\section{Latar Belakang}

Literasi keuangan merupakan kesadaran keuangan dan pengetahuan tentang produk-produk keuangan, lembaga keuangan dan konsep mengenai keterampilan dalam mengelola keuangan (Xu dan Zia 2012). Menurut Otoritas Jasa Keuangan (2016) literasi keuangan adalah pengetahuan, keterampilan, dan keyakinan yang memengaruhi sikap dan perilaku untuk meningkatkan kualitas pengambilan keputusan dan pengelolaan keuangan dalam rangka mencapai kesejahteraan. Dengan definisi ini diharapkan konsumen produk dan jasa keuangan maupun masyarakat luas tidak hanya mengetahui dan memahami lembaga jasa keuangan, serta produk dan jasa keuangan, melainkan juga dapat mengubah atau memperbaiki perilaku masyarakat dalam pengelolaan keuangan sehingga mampu meningkatkan kesejahteraan mereka. Dalam beberapa tahun terakhir, financial literacy telah menjadi topik yang diminati, karena pasar keuangan telah menjadi kompleks dan sulit untuk membuat pilihan berdasarkan informasi. Sektor perekonomian juga berkembang dan mengakibatkan kebutuhan individu juga mengalami perkembangan. Hal tersebut menyebabkan pengetahuan keuangan atau yang sering di sebut financial literacy menjadi salah satu aspek yang harus diperhatikan oleh negara-negara maju dan berkembang. 
Tujuan akhir dari stabilitas keuangan dapat dicapai melalui financial literacy secara menyeluruh di negara maju dan khususnya di negara-negara berkembang Survei Nasional Literasi Keuangan (SNLIK) ketiga yang dilakukan Otoritas Jasa Keuangan (OJK) pada tahun 2019 menunjukkan indeks literasi keuangan mencapai 38,03\% dan indeks inklusi keuangan $76,19 \%$. Angka tersebut meningkat dibanding hasil survei OJK 2016 yaitu indeks literasi keuangan 29,7\% dan indeks inklusi keuangan $67,8 \%$.

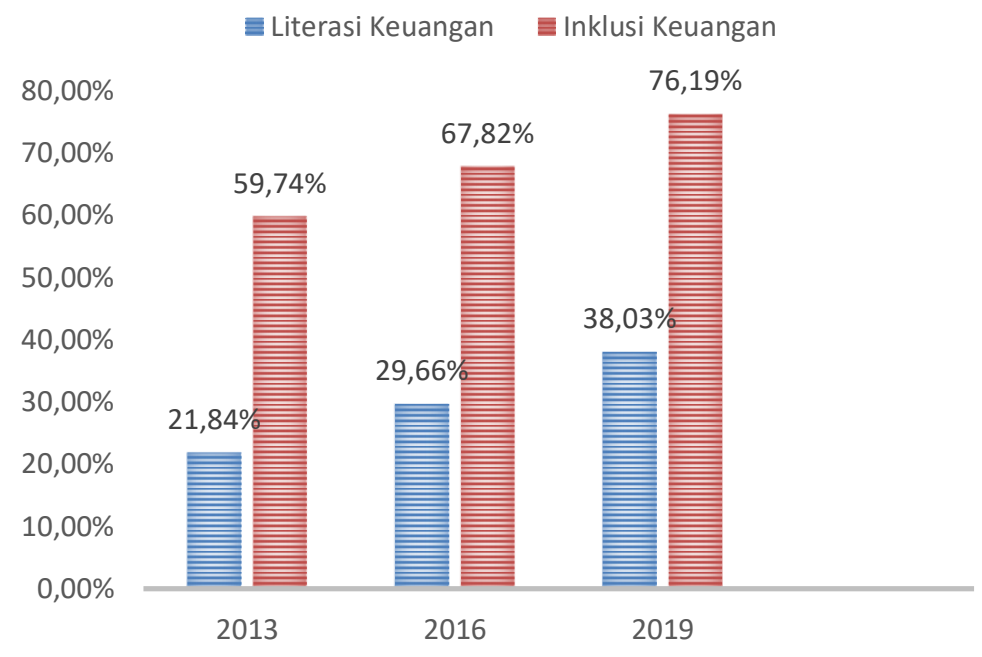

Gambar 1 Tingkat Literasi Keuangan dan Inklusi Keuangan Nasional Sumber : Otoritas Jasa Keuangan (2019)

Namun menurut Presiden RI Joko Widodo (Jokowi), meskipun tingkat inklusi dan literasi keuangan di Indonesia setiap tahunnya semakin meningkat tetapi tingkat inklusi dan literasi keuangan Indonesia masih tertinggal dibanding negara lain di Asean, seperti negara Singapura sampai 98 persen, kita masih di angka 70 persen, Malaysia 85 persen, Thailand 82 persen. Negara-negara maju antara lain Amerika, Kanada, Jepang dan Australia sedang gencar melakukan edukasi literasi keuangan pada masyarakat terutama mahasiswa dengan harapan dapat meningkatkan tingkat literasi keuangan masyarakat. Mahasiswa akan menghadapi permasalahan dan lingkungan baru yang belum pernah dialami sebelumnya dan mahasiswa juga harus bisa mengelola dan mengatur keuangannya secara mandiri.

Permasalahan keuangan yang sering timbul adalah mereka yang masih mengandalkan uang dari orangtua, sikap boros dan banyak mahasiswa yang menyalurkan atau menggunakan uang sakunya kedalam hal yang kurang penting. Mahasiswa merupakan salah satu pihak yang menjadi proritas sasaran dan kegiatan Literasi Keuangan. Hal ini disebabkan mahasiswa dapat berperan sebagai agen perubahan. Sebagai golongan masyarakat yang intelektual peranan mahasiswa sangat dibutuhkan dan penting dalam perubahan bangsa. Mahasiswa dapat menggunakan teori yang di pelajarinya di kampus untuk menyelesaikan permasalahan yang terjadi di masyarakat. Mahasiswa diharapkan selalu berpikir kritis dalam menyelesaikan masalah yang ada di masyarakat dan dapat memberikan solusi. Mahasiswa sebagai sumberdaya terdidik dan terpelajar seharusnya memiliki literasi dalam penggunaan dana. Literasi keuangan meliputi bidang-bidang luas yaitu pengeluran dan kredit, asuransi, serta tabungan dan investasi. Oleh karena itu sangat di perlukan literasi keuangan yang memungkinkan para mahasiswa asal dalam berinvestasi karena seseorang yang memiliki financial literacy yang rendah akan sangat rentan mengalami penipuan memberikan iming-iming return yang besar dalam waktu yang singkat.

Selain financial literacy, ada faktor lain yang mempengaruhi inklusi keuangan yaitu Financial - Seiring berkembangnya teknologi informasi dan didukung tingkat penetrasi internet yang pesat, muncullah beberapa layanan jasa keuangan digital yang mempermudah masyarakat dalam melakukan transaksi dan untuk memperoleh pembiayaan. Layanan digital keuangan ini disebut financial technology yang kemudian disingkat menjadi Fintech. Distribusi perusahaan Fintech di Indonesia pada tahun 2018 dapat dilihat pada Gambar 2 berdasarkan survey Fintech News 
Singapore. Masyarakat Indonesia lebih banyak menggunakan layanan Fintech berbasis pembayaran dengan persentase $38 \%$ dan diikuti oleh layanan pinjaman sebesar $31 \%$. Hal ini menunjukkan ketersediaan Fintech di Indonesia mampu membantu pemerintah dalam menyediakan layanan keuangan pembayaran dan pinjaman yang lebih luas dan efisien. Total nilai investasi pada Fintech di Indonesia tahun 2017 mencapai 2.29 triliun rupiah menurut data Daily Social and Statistics pada Laporan Fintech Indonesia (2018). Laporan World Economic Forum (2015) dalam artikel Fintech Indonesia, memprediksikan bahwa negara Indonesia akan menjadi salah satu pasar digital terbesar di Asia Tenggara pada tahun 2020. Prediksi tersebut menunjukkan peluang berkembangnya layanan keuangan digital di Indonesia dalam waktu dekat untuk memenuhi kebutuhan layanan jasa keuangan bagi masyarakat.

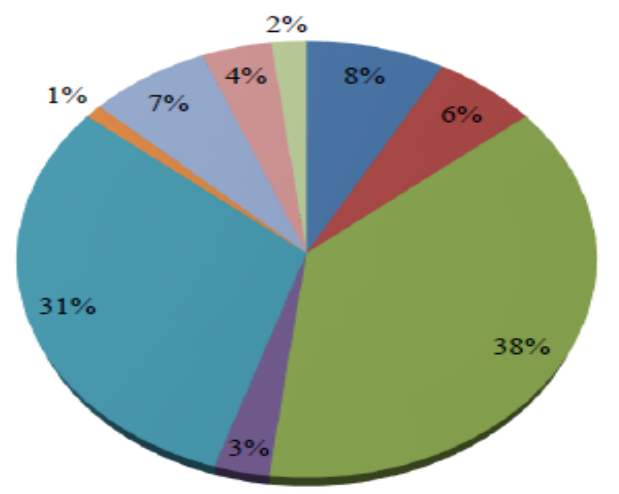

$$
\begin{aligned}
& \text { - Personal finance } \\
& \text { - Insurtech } \\
& \text { = Payment } \\
& \text { - POS } \\
& \text { - Lending } \\
& \text { - Accounting } \\
& \text { - Comparison } \\
& \text { - Crowdfunding } \\
& \text { - Cryptocurrency }
\end{aligned}
$$

Gambar 2 Distibusi Fintech di Indonesia pada tahun 2018 Sumber : Fintech News Singapore 2018

Perkembangan teknologi dan fintech di Indonesia harus di imbangi juga dengan literasi digital yang didefinisikan sebagai kemampuan untuk memahami dan menggunakan informasi dari berbagai sumber digital. Jadi sebagai seorang individu yang hidup dalam perkembangan fintech serta inklusi keuangan diperlukan sebuah literasi digital juga agar bisa berpikir secara kritis untuk melakukan evaluasi terhadap informasi yang ditemukan melalui media digital. Ada satu fakta unik di balik perkembangan financial , yakni sasaran target pengguna jasa tersebut. Usut punya usut, andil dari generasi millenial sangatlah besar bahkan yang tertinggi saat ini. Menurut data yang diambil dari Asosiasi Financial technology Indonesia (AFTECH), generasi millenial menjadi pengguna tertinggi metode keuangan modern ini. Munculnya generasi millenial sebagai pengguna fintech terbanyak bukanlah hal yang aneh. Sebab, kebiasaan mereka menghabiskan waktu di pusat perbelanjaan menjadi salah satu contohnya. Mulai dari nongkrong, minum kopi di tempat ternama hingga enonton bioskop, semua hal itu mereka bayar melalui smartphone.

Tabel 1 Mini Survey Tingkat Literasi Keuangan dan Inklusi Keuangan Mahasiwa Institut Ilmu Sosial dan Manajemen STIAMI Jakarta Kampus Bekasi

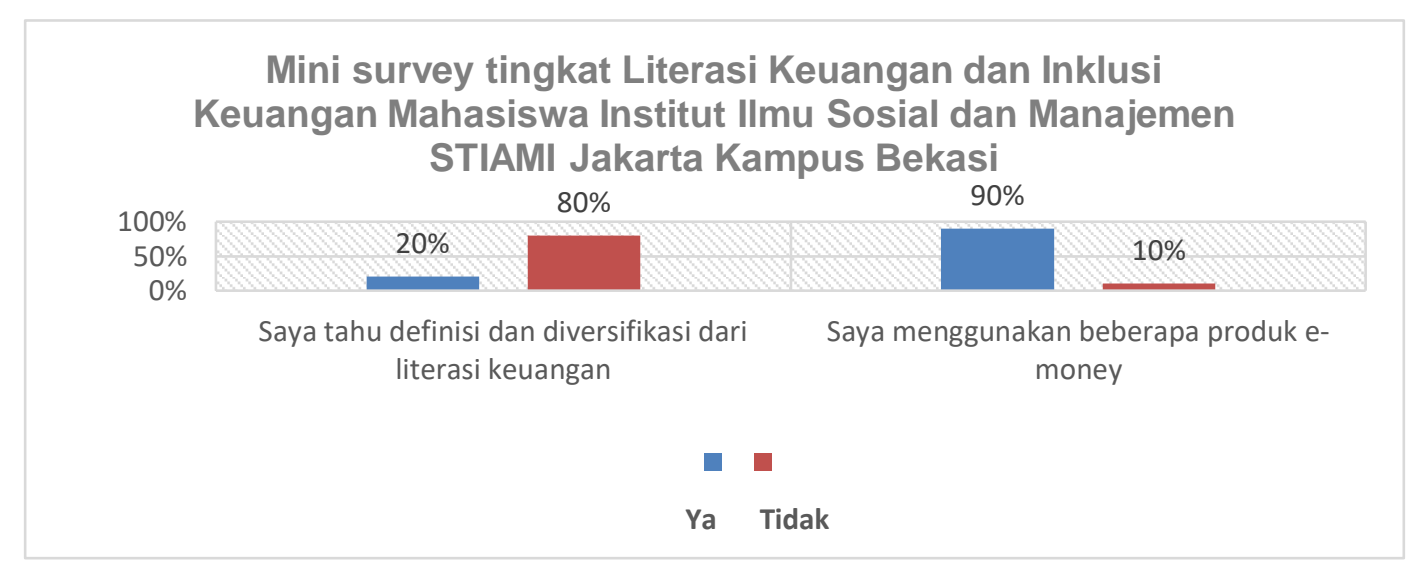

Sumber : Diolah Sendiri 
Berdasarkan hasil mini survey kepada 20 mahasiswa Institut Ilmu Sosial dan Manajemen STIAMI Jakarta Kampus Bekasi dengan memberikan pertanyaan tertutup mengenai "Apakah anda tahu definisi dan diversifikasi dari literasi keuangan?" dan "Apakah anda menggunakan beberapa produk e-money?" Hasil mini survey menunjukkan bahwa $80 \%$ responden tidak tahu definisi dan diversifikasi dari literasi keuangan serta $20 \%$ lainnya menjawab tahu definisi dan diversifikasi dari literasi keuangan dan untuk pertanyaan lainnya menunjukkan bahwa $90 \%$ responden menjawab menggunakan beberapa produk e-money dan $10 \%$ lainnya menjawab tidak menggunakan produk $e$ money.

Dengan fenomena yang terjadi ini maka peneliti ingin mengetahui bagaimana gambaran tingkat literasi keuangan pada mahasiswa khususnya di Kota Bekasi. Kota Bekasi dipilih karena merupakan kota dengan peringkat ke-29 dengan predikat Sangat Inovatif dari 514 Kota/Kabupaten se-Indonesia. Hal itu berdasarkan penilaian Badan Penelitian dan Pengembangan Kementerian Dalam Negeri. Menjadi salah satu kota ter-Inovatif memungkinkan kota Bekasi sebagai tempat pertumbuhan inklusi yang terbesar dan sasaran perusahaan fintech. Didasarkan fenomena yang terjadi maka peneliti ingin meneliti kondisi mahasiswa Institut Ilmu Sosial dan Manajemen STIAMI Jakarta Kampus Bekasi di Kota Bekasi untuk menganalisis tingkat literasi keuangan, financial technology, dan inklusi keuangan

Tujuan dari penelitian ini adalah untuk menganalisa :

1. Seberapa besar pengaruh Literasi Keuangan terhadap Inklusi Keuangan Mahasiswa Institut Ilmu Sosial dan Manajemen STIAMI Jakarta Kampus Bekasi.

2. Seberapa besar pengaruh Financial terhadap Inklusi Keuangan Mahasiswa Institut Ilmu Sosial dan Manajemen STIAMI Jakarta Kampus Bekasi.

3. Seberapa besar pengaruh Literasi Keuangan dan Financial terhadap Inklusi Keuangan Mahasiswa Institut Ilmu Sosial dan Manajemen STIAMI Jakarta Kampus Bekasi secara simultan.

\section{Perumusan Masalah}

Berdasarkan latar belakang masalah dan tujuan penelitian di atas, maka rumusan masalah dalam penelitian ini adalah:

1. Seberapa besar pengaruh Literasi Keuangan terhadap Inklusi Keuangan Mahasiswa Institut Ilmu Sosial dan Manajemen STIAMI Jakarta Kampus Bekasi?

2. Seberapa besar pengaruh Financial Technology terhadap Inklusi Keuangan Mahasiswa Institut Ilmu Sosial dan Manajemen STIAMI Jakarta Kampus Bekasi?

3. Seberapa besar pengaruh Literasi Keuangan dan Financial terhadap Inklusi Keuangan Mahasiswa Institut Ilmu Sosial dan Manajemen STIAMI Jakarta Kampus Bekasi secara simultan?

\section{LANDASAN TEORI}

\section{Literasi Keuangan}

Menurut Abdullah, Muhammad Azmi \& Chong dalam kusumaningrum (2014) Financial literacy isi also the combination of consumers or investors understanding of financial products and concepts and their ability and confidence to appreciate financial risks and opportunities to make informal choices, to know where to go for help and to take other effective actions to inprove their financial well being.

Menurut Otoritas Jasa Keungan (OJK) yang dikutip dalam Kusumaningrum (2014) literasi keuangan (Financial Literacy) didefinisikan sebagai tingkat pengetahuan, keterampilan, keyakinan masyarakat terkait lembaga keuangan serta produk dan jasanya yang dituangkan dalam parameter ukuran indeks.

Saat ini Gerakan Sadar Keuangan/financial literacy di Indonesia, sangat didukung oleh Pemerintah. Meningkatkan Literasi Keuangan bagi masyarakat Indonesia, merupakan stategi 
nasional yang ditugaskan/diamanatkan kepada otoritas jasa keuangan (OJK). Tingkat Literasi Keuangan menurut Jasa Otoritas Keuangan (2013) dibedakan menjadi:

1) Well Literate. Pada tahap ini, seseorang memiliki pengetahuan dan keyakinan tentang lembaga jasa keuangan serta produk dan jasa keuangan, termasuk fitur, manfaat dan risiko, hak dan kewajiban terkait produk dan jasa keuangan, serta memiliki keterampilan dalam menggunakan produk dan jasa keuangan

2) Suff Literate. Pada tahap ini, seseorang memiliki pengetahuan dan keyakinan tentang lembaga jasa keuangan serta produk dan jasa keuangan, termasuk fitur, manfaat dan risiko, hak dan kewajiban terkait produk dan jasa keuangan.

3) Less Literate. Pada tahap ini, seseorang hanya memiliki pengetahuan tentang lembaga jasa keuangan, produk dan jasa keuangan

4) Not Literate. Pada tahap ini, seseorang tidak memiliki pengetahuan dan keyakinan tentang lembaga jasa keuangan serta produk dan jasa keuangan, serta tidak memiliki keterampilan dalam menggunakan produk dan jasa keuangan.

Menurut Atkinson dan Messy (2012) dan dikembangkan oleh Organisation for Economic Co-operation and Development (2016), terdapat 3 komponen yang digunakan untuk mengukur tingkat literasi keuangan resonden ialah :

a. Pengetahuan financial (financial knowledge)

b. Perilaku financial (financial behaviour)

c. Sikap financial (financial attitude)

Financial technology

Menurut Pribadiono, Hukum, Esa, \& Barat (2016), Financial (FinTech) merupakan perpaduan antara teknologi dan fitur keuangan atau dapat juga diartikan inovasi pada sektor finansial dengan sentuhan teknologi modern.

Menurut Dorfleitner, Hornuf, Schmitt, \& Weber (2017), FinTech merupakan industri yang bergerak dengan sangat cepat dan dinamis dimana terdapat banyak model bisnis yang berbeda.

Menurut Hsueh (2017), Teknologi Keuangan juga disebut sebagai FinTech, merupakan model layanan keuangan baru yang dikembangkan melalui inovasi teknologi informasi.

Menurut OECD (2016), memahami dampak dan implikasi perkembangan Fintech dapat didekati dengan tiga dimensi, diantaranya :

1) Teknologi

Contohnya seperti DLT (Distributed Ledger Technology), dan kemudian lihat aplikasi teknologi ini untuk layanan keuangan dan implikasi potensial yang dapat dimilikinya.

2) Aplikasi

Melihat aplikasi tertentu, seperti crowdfunding, dan pertimbangkan implikasi khusus untuk aplikasi ini.

3) Aspek

Cara ketiga adalah memulai dengan fokus pada dampak dari perubahan-perubahan ini, seperti peningkatan risiko siber, dan apa yang tersirat dari perubahan ini untuk tujuan kebijakan tertentu. 


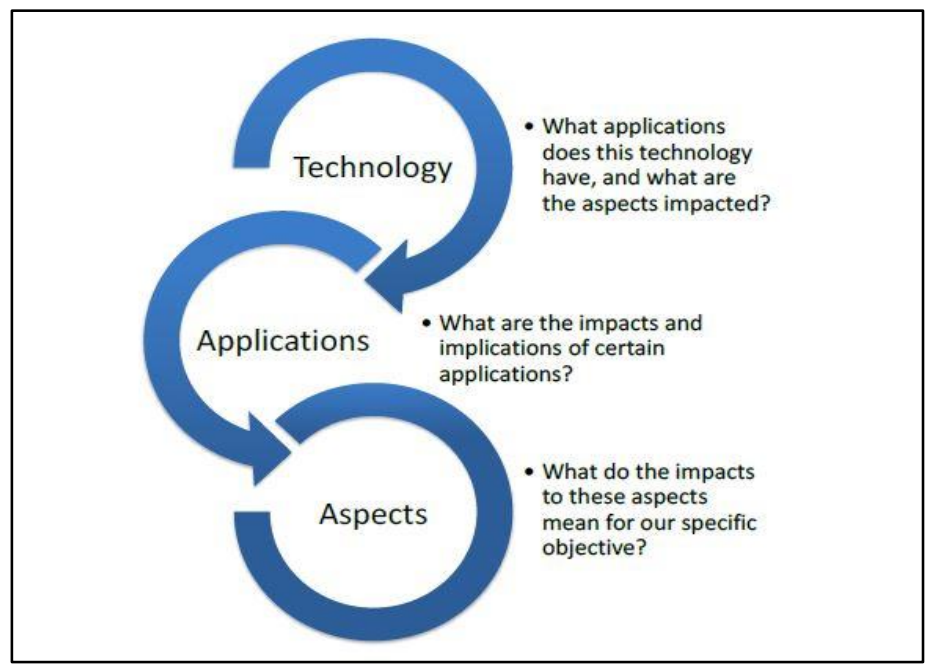

Gambar 3. Dimensi Financial technology

Sumber : Organisation for Economic Cooperation and Development (OECD)

Tipe-tipe Financial technology (Fintech) Menurut Hsueh (2017), Terdapat tiga tipe financial technology yaitu :

1) Sistem pembayaran melalui pihak ketiga (Third-party payment systems). Contoh - contoh sistem pembayaran melalui pihak ketiga yaitu crossborder EC, online-to-offline $(\mathrm{O} 2 \mathrm{O})$, sistem pembayaran mobile, dan platform pembayaran yang menyediakan jasa seperti pembayaran bank dan transfer.

2) Peer-to-Peer (P2P) Lending, Peer-to-Peer Lending merupakan platform yang mempertemukan pemberi pinjaman dan peminjam melalui internet. Peer-to-Peer Lending menyediakan mekanisme kredit dan manajemen risiko. Platform ini membantu pemberi pinjaman dan peminjam memenuhi kebutuhan masing-masing dan menghasilkan penggunaan uang secara efisien.

3) Crowdfunding, Crowdfunding merupakan tipe FinTech di mana sebuah konsep atau produk seperti desain, program, konten, dan karya kreatif dipublikasikan secara umum dan bagi masyarakat yang tertarik dan ingin mendukung konsep atau produk tersebut dapat memberikan dukungan secara finansial. Crowdfunding dapat digunakan untuk mengurangi kebutuhan finansial kewirausahaan, dan memprediksi permintaan pasar.

\section{Inklusi Keuangan}

Menurut Kementerian Keuangan (2013), Inklusi Keuangan adalah bentuk strategi nasional Inklusi Keuangan yaitu hak setiap orang untuk memiliki akses dan layanan penuh dari lembaga keuangan secara tepat waktu, nyaman, informatif, dan terjangkau biayanya, dengan penghormatan penuh kepada harkat dan martabat.

Menurut Salim (2014), Inklusi Keuangan adalah suatu keadaan dimana mayoritas individu dapat memanfaatkan jasa keuangan yang tersedia serta meminimalisir adanya kelompok individu yang belum sadar akan manfaat akses keuangan melalui akses yang telah tersedia tanpa biaya yang tinggi.

Menurut Sanjaya (2014), Inklusi Keuangan adalah penyediaan akses bagi masyarakat termarginalkan (lebih kepada masyarakat miskin) dengan tujuan agar dapat memiliki dan menggunakan layanan sistem keuangan.

Menurut Bank Dunia (2015), Inklusi Keuangan adalah kondisi ketika setiap anggota masyarakat mempunyai akses terhadap berbagai layanan keuangan formal yang berkualitas secara tepat waktu, lancar, dan aman dengan biaya terjangkau yang disesuaikan dengan kebutuhan dan kemampuan yang bertujuan untuk meningkatkan kesejahteraan masyarakat.

Menurut OECD (2016), terdapat dimensi yang dapat digunakan untuk mengukur tingkat inklusi keuangan, diantaranya : 


\section{Product holding}

Terdapat empat indikator yang mengidentifikasi produk keuangan yang saat ini dimiliki oleh responden, yaitu tabungan atau produk pensiun, produk pembayaran, giro, atau e-money (tidak termasuk kartu kredit), asuransi, dan produk kredit atau hipotek. Indikator ini dapat mengeksplorasi apakah konsumen setidaknya sadar akan produk keuangan yang tersedia secara nasional, apakah mereka membuat pilihan produk keuangan, dan apakah mereka telah beralih ke keluarga atau teman untuk membantu mereka menghemat uang atau memenuhi kebutuhan.

\section{Product awareness}

Selain memiliki produk keuangan, kesadaran akan penggunaan produk sesuai kebutuhan juga penting. Kesadaran ini akan mencegah kesalahan pemilihan dan membantu penyedia produk keuangan untuk mengetahui permintaan dari masyarakat.

\section{Product choice}

Inklusi keuangan sangat menguntungkan konsumen jika produk keuangan yang dimiliki dipantau dengan baik. Perlu dilakukan perubahan jika terdapat produk atau layanan jasa keuangan baru atau ketika struktur harga berubah. Sebaliknya, konsumen yang mengambil produk keuangan dapat mengalami kerugian jika tidak mengelola dengan baik. Misalnya, memegang asuransi yang tidak memenuhi kebutuhan mereka, produk kredit yang membebankan karena tingkat bunga yang tinggi atau mengunakan layanan transaksi yang tidak perlu dengan fasilitas pembayaran yang mahal.

\section{Seeking alternatives to formal financial services}

Indikator terakhir digunakan untuk mengidentifikasi masyarakat yang berpotensi tidak memiliki akses ke layanan keuangan formal. Pertanyaan menggambar pada dua hal yakni, apakah masyarakat beralih ke keluarga atau teman untuk dukungan keuangan. Hasilnya mencerminkan beberapa faktor, termasuk sejauh mana orang-orang secara aktif menabung dengan cara apa pun dan sejauh mana mereka memenuhi kebutuhan. Tetapi juga menunjukkan bahwa mungkin ada ruang untuk merancang produk sederhana dan murah untuk memenuhi kebutuhan konsumen.

\section{Kerangka Teori}

Untuk mengungkap permasalahan yang akan dibahas dalam penyusunan usulan penelitian ini, maka peneliti menggunakan kerangka penelitian yaitu berupa skema seperti dibawah ini :

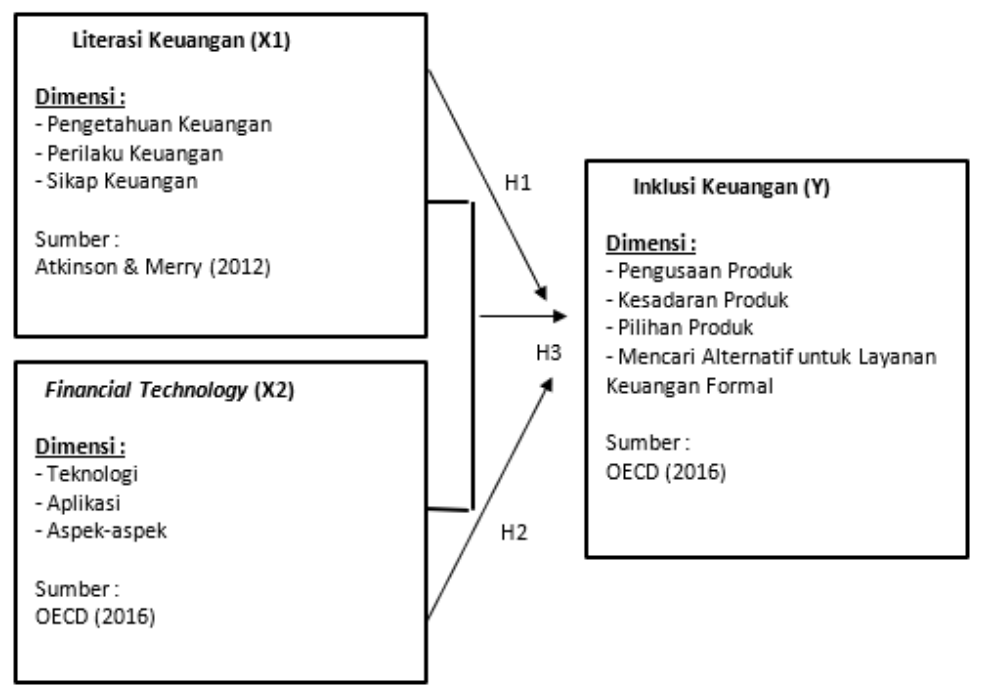

Gambar 4 Kerangka Teori

Sumber : Dikembangkan dalam penelitian ini 


\section{METODE PENELITIAN}

Penelitian menggunakan metode deskriptif kuantitatif dengan menggunakan kuisioner. Kuesioner ini disusun dalam bentuk pernyataan dan disediakan kolom jawab dengan menggunakan skala interval. Jawaban berisi pertanyaan yang menyatakan sangat setuju dengan skor 5, setuju dengan skor 4, netral dengan skor 3, tidak setuju dengan skor 2 dan sangat tidak setuju dengan skor 1. Teknik pengambilan sampel dilakukan dengan menggunakan purposive sampling dimana sampel diambil dengan pertimbangan tertentu. Teknik ini dilakukan untuk mendapatkan sampel yang sesuai dengan kebutuhan penelitian. Sampel yang ditetapkan harus mahasiswa Strata 1 Institut Ilmu Sosial dan Manajemen STIAMI Jakarta Kampus Bekasi, Fakultas Ilmu Administrasi Program Studi Administrasi Bisnis, angkatan 2019-2020 sebanyak 476 orang. Sedangkan pengambilan sample sesuai Suharsimi Arikunto (2010: 112), "jika subjeknya besar atau lebih dari 100 orang dapat diambil $10-15 \%$ atau 20-25\% atau lebih". Maka dengan ini penulis mengambil sample sebesar $10 \%$ dari jumlah populasi yang ada. Yaitu sebesar 47 orang. Sedangkan Teknik Pengambilan Sampel adalah simple random sampling.

\section{Profil Responden}

Responden dalam penelitian ini adalah 47 mahasiswa Institut Ilmu Sosial dan Manajemen STIAMI. Data umum responden disini akan menjelaskan gambaran umum mengenai karakteristik responden berdasarkan jenis kelamin, usia, dan penghasilan. Karakteristik responden berdasarkan jenis kelamin terdapat dua kategori yaitu laki - laki (43\%) dan perempuan (57\%). Hal ini dilakukan untuk mengetahui seberapa banyak jumlah dan besarnya persentase yang mendominasi pada karakteristik responden berdasarkan jenis kelamin. Jumlah responden berusia $<25$ tahun sebanyak 20 responden (43\%), selanjutnya adalah jumlah responden terbanyak berusia $25-35$ Tahun yaitu sebanyak 25 responden $(53 \%)$, dan responden yang berusia $>35$ tahun sebanyak 2 responden $(4 \%)$. Sedangkan responden dengan pengeluaran <Rp. 1.000 .000 sebanyak 6 responden (13\%), selanjutnya jumlah responden dengan pengeluaran Rp. 1.000 .000 - Rp. 3.000 .000 sebanyak 31 responden $(66 \%)$, dan jumlah responden dengan pengeluaran >Rp. 3.000 .000 sebanyak 10 responden $(21 \%)$.

\section{Teknik Analisis Data}

Teknik analisis data yang digunakan dalam penelitian ini adalah analisis datasecara kuantitatif. Meliputi Analisis rata - rata tanggapan responden dengan menggunakan skala Likert untuk mendapatkan data - data yang diperlukan. Analisis regresi linear sederhana digunakan untuk mengetahui apakah variabel bebas (X) yaitu literasi keuangan dan financial technology searah bersamaan mempengaruhi variabel terkait $(\mathrm{Y})$ yaitu Inklusi keuangan Mahasiswa Institut Ilmu Sosial dan Manajemen STIAMI Jakarta Kampus Bekasi. Analisis Linier Berganda untuk menguji hipotesis dan menyatakan kejelasan tentang kekuatan variabel penentu yaitu keputusan pembelian. Lalu Analisis Angka Penafsiran Weight Mean Score (WMS); Analisis Koefisien Korelasi Sederhana disebut juga dengan Koefisien Korelasi Pearson untuk mengukur kuat tidaknya hubungan antara variabel. Uji signifikan parameter individual (uji statistik t) untuk menunjukkan seberapa jauh pengaruh suatu variabel independen secara individual dalam menerangkan variasi dependen. Uji $\mathrm{F}$ digunakan untuk mengetahui tingkat signifikansi pengaruh variabel-variabel independen secara bersama-sama (simultan) terhadap variabel dependen. Dan Uji Koefisien determinasi yang menjelaskan besarnya pengaruh nilai variabel $X$ terhadap naik atau turunnya variabel Y. Analisis dilakukan setelah data terkumpul. Selanjutnya dilakukan penarikan kesimpulan.

\section{HASIL DAN PEMBAHASAN}

Uji Koefisien Determinasi digunakan untuk mengetahui seberapa besar pengaruh variabel bebas terhadap variabel tidak bebas. Nilai yang digunakan dalam koefisien determinasi adalah dengan menggunakan nilai R Square pada tabel summary.

Berikut hasil Uji Koefisien Korelasi Determinasi R2 menggunakan SPSS Versi 25 
Tabel 1. Hasil Uji Koefisien Determinasi Literasi keuangan (X1) Terhadap Inklusi keuangan (Y)

Model Summary

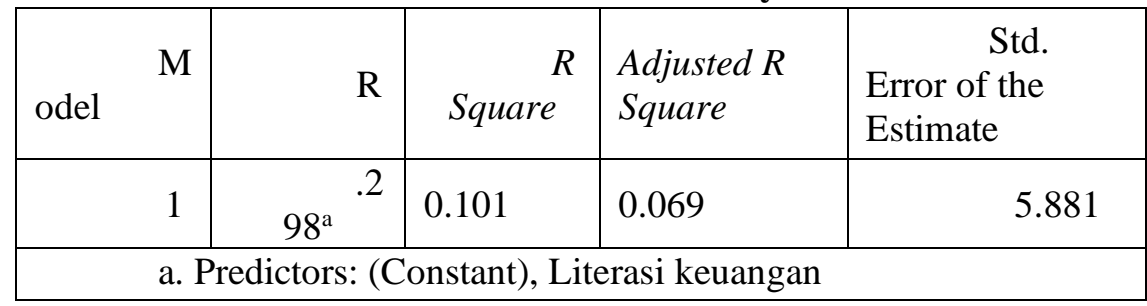

Sumber : Data Output SPSS versi 25

Berdasarkan hasil output diatas diketahui nilai $\mathrm{R}$ sebesar 0.298 dan nilai $\mathrm{R}$ square sebesar 0.089 , Kemudian hasil tersebut didistribusikan ke dalam rumus berikut:

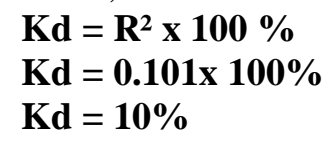

Berdasarkan perhitungan diatas dapat diartikan bahwa ada pengaruh variabel literasi keuangan (X1) terhadap variabel inklusi keuangan (Y) sebesar 10\%. Sedangkan sisanya $(100 \%-10 \%=$ 90\%) dipengaruhi oleh faktor lain yang tidak dibahas dalam penelitian ini.

Tabel 2. Hasil Uji Koefisien Determinasi Financial technology (X2) Terhadap Inklusi keuangan (Y)

\begin{tabular}{|c|c|c|c|c|}
\hline \multicolumn{5}{|c|}{ Model Summary } \\
\hline odel & $\mathrm{R}$ & Square & $\begin{array}{l}\text { Adjusted } R \\
\text { Square }\end{array}$ & $\begin{array}{l}\text { Std. Error of } \\
\text { the Estimate }\end{array}$ \\
\hline 1 & $63^{a^{a}}$ & 0.617 & 0.302 & 5.093 \\
\hline \multicolumn{5}{|c|}{ a. Predictors: (Constant), Financial technology } \\
\hline
\end{tabular}

Berdasarkan hasil output diatas diketahui nilai $\mathrm{R}$ sebesar 0.863 dan nilai $\mathrm{R}$ square sebesar 0.617 , Kemudian hasil tersebut didistribusikan ke dalam rumus berikut:

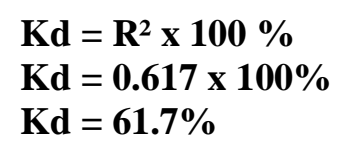

Berdasarkan perhitungan diatas dapat diartikan bahwa ada pengaruh variabel financial technology (X2) terhadap variabel inklusi keuangan (Y) sebesar $61.7 \%$. sedangkan sisanya $(100 \%$ $-61.7 \%=38.3 \%$ ) dipengaruhi oleh faktor lain yang tidak dibahas dalam penelitian ini.

Tabel 3. Koefisien Determinasi Hasil Uji Koefisien Determinasi Literasi keuangan (X1) dan Financial technology (X2) Terhadap Inklusi keuangan (Y)

Model Summary

\begin{tabular}{|r|r|r|r|c|}
\hline odel & $\mathrm{R}$ & $\begin{array}{c}\mathrm{R} \\
\text { Square }\end{array}$ & $\begin{array}{c}\text { Adjust } \\
\text { ed R Square }\end{array}$ & $\begin{array}{c}\text { Std. } \\
\text { Error of the } \\
\text { Estimate }\end{array}$ \\
\hline 1 & $68^{\mathrm{a}}$ & 0.623 & 0.292 & 5.129 \\
\hline \multicolumn{4}{|c|}{ a. Predictors: (Constant), Literasi keuangan, Financial } \\
technology
\end{tabular}

Sumber : Data Output SPSS versi 25 
Berdasarkan hasil output diatas diketahui nilai $\mathrm{R}$ sebesar 0.768 dan nilai $\mathrm{R}$ square sebesar 0.523 , Kemudian hasil tersebut didistribusikan ke dalam rumus berikut:

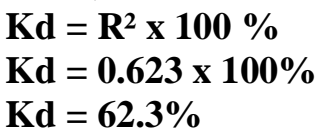

Berdasarkan perhitungan diatas dapat diartikan bahwa ada pengaruh variabel literasi keuangan (X1) dan variabel financial technology (X2) terhadap variabel inklusi keuangan (Y) sebesar $52.3 \%$. sedangkan sisanya $(100 \%-62.3 \%=37.7 \%)$ dipengaruhi oleh faktor lain yang tidak dibahas dalam penelitian ini.

Sesuai dengan tujuan peneliti untuk mengetahui pengaruh literasi keuangan terhadap inklusi keuangan dan pengaruh financial terhadap inklusi keuangan. Maka akan dibahas hal - hal sebagai berikut :

\section{Pengaruh Literasi keuangan (X1) terhadap Inklusi keuangan (Y)}

Hasil penelitian menunjukan bahwa variabel literasi keuangan tidak terdapat pengaruh terhadap inklusi keuangan Mahasiswa Institut Ilmu Sosial dan Manajemen STIAMI Jakarta kampus Bekasi. Hal tersebut dapat terlihat dari nilai positif koefisien literasi keuangan yakni sebesar 0.095 . Berdasarkan hasil uji parsial diperoleh nilai t hitung $0.607<\mathrm{t}$ tabel 2.0137 atau signifikasi $0.547>$ 0.05. Sehingga dapat disimpulkan bahwa Ho diterima dan Ha ditolak yang berarti tidak terdapat pengaruh yang signifikan literasi keuangan (X1) terhadap inklusi keuangan (Y)

\section{Pengaruh Financial technology (X2) terhadap Inklusi keuangan (Y)}

Hasil penelitian menunjukan bahwa variabel financial technology terdapat pengaruh terhadap inklusi keuangan Mahasiswa Institut Ilmu Sosial dan Manajemen STIAMI Jakarta kampus Bekasi. Hal tersebut dapat terlihat dari nilai positif koefisien financial yakni sebesar 1.140. Berdasarkan hasil uji parsial diperoleh nilai t hitung $3.895>\mathrm{t}$ tabel 2.0137 atau signifikasi $0.000<0.05$. Sehingga dapat disimpulkan bahwa Ho ditolak dan Ha diterima yang berarti terdapat pengaruh yang signifikan financial (X2) terhadap inklusi keuangan (Y) Mahasiswa Institut Ilmu Sosial dan Manajemen STIAMI Jakarta kampus Bekasi.

\section{Pengaruh Literasi keuangan (X1) dan Financial (X2) terhadap Inklusi keuangan (Y)}

Hasil penelitian menunjukan bahwa variabel literasi keuangan dan financial terdapat pengaruh terhadap inklusi keuangan Mahasiswa Institut Ilmu Sosial dan Manajemen STIAMI Jakarta kampus Bekasi. Hal tersebut dapat terlihat dari hasil uji F diperoleh nilai F hitung $10.476>\mathrm{F}$ tabel 3.20 atau signifikasi $0.000<0.05$. Sehingga dapat disimpulkan bahwa Ho ditolak dan Ha diterima yang berarti terdapat pengaruh signifikan literasi keuangan (X1) dan financial (X2) terhadap inklusi keuangan (Y) Mahasiswa Institut Ilmu Sosial dan Manajemen STIAMI Jakarta kampus Bekasi.

\section{KESIMPULAN}

1. Besar pengaruh Literasi Keuangan (X1) terhadap Inklusi Keuangan (Y) Mahasiswa Insitut Ilmu Sosial dan Manajemen STIAMI Jakarta kampus Bekasi dalam penelitian ini adalah sebesar 10\%, sedangkan sisanya sebesar $90 \%$ dipengaruhi oleh variabel lain yang tidak dibahas dalam penelitian ini.

2. Besar pengaruh Financial (X2) terhadap Inklusi Keuangan (Y) Mahasiswa Insitut Ilmu Sosial dan Manajemen STIAMI Jakarta kampus Bekasi dalam penelitian ini adalah sebesar $61.7 \%$, sedangkan sisanya sebesar $38.3 \%$ dipengaruhi oleh variabel lain yang tidak dibahas dalam penelitian ini.

3. Besar pengaruh Literasi Keuangan (X1) dan Financial (X2) terhadap Inklusi Keuangan (Y) Mahasiswa Insitut Ilmu Sosial dan Manajemen STIAMI Jakarta kampus Bekasi sebesar 62.3\%, sedangkan sisanya sebesar $37.7 \%$ dipengaruhi oleh variabel lain yang tidak dibahas dalam penelitian ini. 


\section{SARAN}

1. Diperoleh temuan bahwa literasi keuangan mempengaruhi inklusi keuangan sesuai dengan pendapat oleh Otoritas Jasa Keuangan. Namun, pada variabel Literasi Keuangan (X1) untuk definisi dan diversifikasi dari Literasi Keuangan terhadap Inklusi Keuangan Mahasiswa Institut Ilmu Sosial dan Manajemen STIAMI sangat rendah. Penelitian selanjutnya diharapkan dapat ditemukan faktor-faktor lain penyebab ketimpangan tingkat literasi keuangan terhadap inklusi keuangan.

2. Hal yang harus ditingkatkan dari variabel Financial (X2) untuk membandingkan produk keuangan terhadap Inklusi Keuangan Mahasiswa Institut Ilmu Sosial dan Manajemen STIAMI agar dapat menemukan produk keuangan yang sesuai dengan kebutuhan dari masing-masing individu. Dengan menyediakan fitur konsultasi dimana konsumen dapat menghubungi pihak Fintech untuk menanyakan produk keuangan yang sesuai dengan produk yang dibutuhkan.

3. Hal yang harus ditingkatkan dari variabel Inklusi Keuangan (Y) adalah fasilitas pembayaran. Sebaiknya perlu ditambahkan fasilitas pembayaran yang terintegrasi dengan satu pintu saja dan bisa kirim kemana saja dengan biaya yang terjangkau dan aman, agar memudahkan konsumen dalam bertransaksi dan tidak selalu membuat akun pengguna baru pada saat pertama kali melakukan transaksi.

\section{DAFTAR PUSTAKA}

\section{Buku:}

Assanuri Sofan, 2016, Pengantar Administrasi Pembangunan, Bandung : Erlangga.

Atmosudidjo, S., Prajudi., Dr., Mr, 2015, Administrasi manajemen umum. Jakarta : CV Mas Haji.

Burhan, 2014, Administrasi Public, Jakarta : Gp. Pross Group

Farland, M., 2013, Ilmu Administrasi negara, Jakarta : Alfabeta

Heizer dan Reider, 2014, Metodelogi Penelitian Sosial, Jakarta : IN MEDIA

Lubis Ibrahim dan Sukarno, 2015, Metodelogi Penelitian, Bandung : Mandar Maju

Porter, 2013, Pengantar Administrasi, Jakarta : PT.Elex media

Saladin, Djaslim,H, 2016, Dasar - Dasar Administrasi, Bandung : Bumi Akara

Stanton, J. William, 2016, Penelitian Administrasi, Jakarta : Salemba Empat

Tjiptono, Fandy, 2017, Pengantar Administrasi, Surabaya : IN MEDIA

\section{Jurnal:}

Abdullah, Mohamad Azmi, and Rosita Chong. "Financial Literacy: An Exploratory Review of the Literature and Future Research." Journal of Emerging Economies \& Islamic Research 2.3 (2014).

Ali, M. (2009). Pendidikan untuk pembangunan nasional: menuju bangsa Indonesia yang mandiri dan berdaya saing tinggi. Grasindo.

Andryani, Y. D. (2018). Inklusivitas Program" Laku Pandai" (Layanan Keuangan Tanpa Kantor Dalam Rangka Keuangan Inklusif)(Studi Deskriptif Pada Bank Rakyat Indonesia Kantor Cabang Krian) (Doctoral dissertation, Universitas Airlangga).

Dewi, T. B. R. (2017). Dampak Inklusi Keuangan (Financial Inclusion) Terhadap Efektivitas Kebijakan Moneter di Indonesia.

Dewi, V. I., \& Barlian, I. (2017). Peran literasi keuangan terhadap perilaku mahasiswa dalam mengelola keuangan. 
Fitriastuti, T., Sari, D. M., \& Purnamasari, I. (2015). Implementasi Kuangan Inkluasi Bagi masyarakat Perbatasan (Studi Kasus pada Kutai Timur, Kabupaten Kutai Kartanegaran dan Kota Samarinda, Kalimantan Timur, Indonesia). SNEMA Universitas Negeri Padang.

Harahap, Berry A., et al. "Perkembangan Financial technology Terkait Central Bank Digital Currency (CBDC) Terhadap Transmisi Kebijakan Moneter Dan Makroekonomi." Bank Indonesia. Retrieved from https://www.bi.go.id/id/publikasi/wp/Documents/WP-2-2017. pdf\% $O A$ (2017).

Hidayat, A. (2017). Peran OJK (Otoritas Jasa Keuangan) Dalam Meningkatkan Literasi Keuangan Pada Masyarakat Terhadap Lembaga Jasa Keuangan (Studi di Kantor OJK Purwokerto) (Doctoral dissertation, IAIN Purwokerto).

Marlina, L., \& Rahmat, B. (2018). Peran Lembaga Keuangan Syariah Dalam Mengimplementasikan Keuangan Inklusif Bagi Pelaku UMKM Tasikmalaya. Jurnal Ecodemica, 2(1).

Marlina, L., \& Rahmat, B. (2018). Peran Lembaga Keuangan Syariah Dalam Mengimplementasikan Keuangan Inklusif Bagi Pelaku UMKM Tasikmalaya. Jurnal Ecodemica, 2(1).

Muzdalifa, I., Rahma, I. A., \& Novalia, B. G. (2018). Peran Fintech Dalam Meningkatkan Keuangan Inklusif Pada UMKM Di Indonesia (Pendekatan Keuangan Syariah). Jurnal Masharif al-Syariah: Jurnal Ekonomi dan Perbankan Syariah, 3(1).

Roberto, A., \& Jaka, W. (2018). Memahami Inklusi Keuangan.

Shen, Na. "Consumer rationality/irrationality and financial literacy in the credit card market: Implications from an integrative review." Financial Literacy and the Limits of Financial Decision Making. Palgrave Macmillan, Cham, 2016. 155-176. 